ROCZNIKI TEOLOGICZNE

Volume 65, issue 7 - 2018

Englis h version

DOI: http://dx.doi.org/10.18290/rt.2018.65.7-4en

\title{
DAMIAN DOROCKI
}

\section{WAS ARMINIUS A REFORMED THEOLOGIAN? ON ARMINIUS' ATTITUDE TO HIS OWN THEOLOGICAL TRADITION}

\begin{abstract}
Jacob Arminius is a figure historically associated with the Reformed tradition. His theology was in a large measure a reflection of this tradition. However, in some important points Arminius' views were in open contradiction to post-Reformation Calvinism. This article is an attempt to find an answer to the question about the theological identity of the Dutch reformer. The author proposes to address this problem in reference to four theological themes characteristic of Reformed Protestantism, that is: God's sovereignty and glory, covenant theology, monergistic soteriology, and predestination. The analysis indicates that Leiden's professor strongly emphasized God's sovereignty over creation and affirmed that the ultimate end of divine actions, including salvific acts, is His glory. But he never forgot to add that, by His external activity, the Creator communicates His goodness. Arminian covenant theology also fits into Reformed thought. Its shape does not differ from the widely accepted interpretation of this issue in the era of "early orthodoxy." The most important differences occur in the context of soteriology. Arminius' understanding of the relationship between grace and free will differed from the radical monergistic Calvinism. Due to the doctrine of prevenient grace, one can speak about limited synergism in his case. His perspective on the issue of predestination is the same. According to the Dutch reformer, God elects to salvation on the basis of His foreknowledge concerning the free acceptance of grace by man. He reprobates those who stubbornly remain in their sins and, in spite of the grace, refuse to convert. Therefore, ultimately, Arminius should be considered as a "critical" Reformed theologian.
\end{abstract}

Keywords: Jacob Arminius; Reformed theology; God's sovereignty and glory; covenant theology; soteriology; predestination.

The attempt to answer the question of whether Arminius was a Reformed theologian encounters a certain problem at the very beginning, because it is necessary to specify what is understood by "Reformed." The easiest way is to adopt the historical criterion and use the adjective "Reformed" to refer to every church (and, consequently, to theologians of every church) that can be

DAMIAN DOROCKI, MA — doctoral student at the Faculty of Theology, Nicolaus Copernicus University in Torun, Poland; address for correspondence-e-mail address: dymek34@ poczta.onet.pl 
shown to be historically linked to the $16^{\text {th }}$-century Reformation-in this case, to its French and Swiss wings. Not all churches wishing to be regarded as Reformed derive directly from the times of the Reformation. It is therefore also legitimate to adopt a theological criterion. The umbrella term of the "Reformed tradition" would then cover everyone who professes official Reformed creeds. Of course, not all churches adopt the same creeds. For instance, the Evangelical Reformed Church in the Republic of Poland recognized the Heidelberg Catechism and the Confession of Sandomierz, which is an adaptation of the Second Helvetic Confession. What is often a marker of doctrinal orthodoxy for some Reformed Christians is the acceptance of the Three Forms of Unity, namely: the Heidelberg Catechism, the Belgic Confession, and the Canons of Dort-this excludes Presbyterians, who follow the Westminster Confession of Faith. Ultimately, "Reformed" should therefore be understood as referring to what is theologically common to all historical Reformed confessions.

Arminius is one of the theologians of the formative period of Calvinist orthodoxy, also referred to as the era of early orthodoxy. Therefore, all the confessions of faith formulated after his (i.e., Arminius') death can, in some measure, serve as comparative material for his thought. For this reason, the decisions of the Synod of Dort (1618-1619) should not be the yardstick against which to assess his views. This was the opinion of Carl Bangs, the author of the best biography of the Leiden professor, who said that looking at his teaching through the lens of Dort was an anachronism, because that Synod took place ten years after Arminius' death. ${ }^{1}$ Carl Bangs points out that the Synod ordered a Latin translation of the Belgic Confession of Faith, which was one of two official confessions in the Dutch Reformed Church in the Leiden scholar's times. Unfortunately, the Latin translation differs in parts from the older Dutch version, and therefore what is known today as the Belgic Confession of Faith was not a document known to Arminius. ${ }^{2}$ The situation is additionally complicated by the fact that in the first half of the $16^{\text {th }}$ century the Netherlands were essentially influenced by the German

\footnotetext{
${ }^{1}$ Cf. Carl BAngs, "Arminius as a Reformed Theologian," in The Heritage of John Calvin. Heritage Hall Lectures, 1960-70, ed. John H. Bratt (Grand Rapids, MI: Eerdmans, 1973), 212, 218. C. Bangs followed the Dutch scholar Gerrit J. Hoenderdaal. Scholars who thought along similar lines and regarded Arminius as a Reformed theologian are: F. Stuart Clarke, John Mark Hicks, Jan Nicolaas Bakhuizen van den Brink, and William G. Witt.

${ }^{2}$ Cf. Carl BAngs, review of God, Creation and Providence in the Thought of Jacob Arminius. Sources and Directions of Scholastic Protestantism in the Era of Early Orthodoxy, by Richard A. Muller, Church History 66 (1997): 120.
} 
Reformation and Anabaptism, and one of the first people propagating the Reformed faith there, Anastasius Veluanus, most certainly did not agree with Calvin and his followers on the issue of predestination. ${ }^{3}$ Richard A. Muller believes that Dort only confirmed the interpretation of the Heidelberg Catechism and Confessio Belgica generally adopted in the Netherlands, citing the synods of the second half of the $16^{\text {th }}$ century (1563-1586), which referred deprecatingly to clerics proclaiming views different from the commonly adopted interpretation. ${ }^{4}$ Also worth noting is the position voiced by William den Boer, who largely agrees with R.A. Muller. There are certain differences between the two scholars, however. First, den Boer does not agree with the American theologian's opinion that Arminius was a synergist. ${ }^{5}$ Second, he points out that the Dutch reformer accepted the contents of the Heidelberg Catechism and the Belgic Confession and was convinced that some of his opponents (e.g., Franciscus Gomarus) went against these documents in their teaching, while he considered himself a man who did not contradict the interpretation provided in them. Muller negates this opinion, citing one of the authors of the Heidelberg Catechism, Zacharias Ursinus, who wrote a commentary on this work. In his commentary, Ursinus excluded the possibility of interpreting the Catechism the way the Leiden scholar interpreted it. William den Boer, however, rightly observes that Catechismus Heidelbergensis was written with a view to creating a common ground for agreement between Lutherans and Calvinists, which is why it is cautious on controversial issues such as predestination. Besides, once a document becomes a commonly adopted

\footnotetext{
${ }^{3}$ Cf. Carl BAngs, "Arminius and the Reformation," Church History 30 (1961): 158-160; Carl BANGS, "Dutch Theology, Trade and War: 1590-1610," Church History 39 (1970): 470-471; Carl BANGS, Arminius. A Study in the Dutch Reformation (Eugene: Wipf\&Stock Publishers, 1998), 21-22. Keith D. Stanglin's words are noteworthy: "Furthermore, Arminius was in some ways part of the nonCalvinistic Dutch Protestant tradition that goes back to the spirit of Anastasius Veluanus"; Keith D. Stanglin, Arminius on the Assurance of Salvation. The Context, Roots, and Shape of the Leiden Debate, 1603-1609 (Leiden-Boston: Brill, 2007), 241.

${ }^{4}$ Cf. Richard A. MulLER, "Historical and Theological Studies. Arminius and the Reformed Tradition," Westminster Theological Journal 70 (2008): 19-48. See also: Fred van LiEBURG, "Gisbertus Samuels, a Reformed Minister Sentenced by the Synod of Zeeland in 1591 for His Opinions on Predestination," in Revisiting the Synod of Dordt (1618-1619), ed. Aza Goudrian and Fred van Lieburg (Leiden-Boston: Brill, 2011), 3-19.

${ }^{5}$ This concerns the relationship between the saving God and the saved man. According to synergists, both parties are active in the work of salvation, which means there is cooperation between man and God. This does not imply their equality, for it is the Creator who initiates salvation and the human being only responds to the Divine initiative. Monergism, by contrast, maintains that only God is the active subject in the salvific relationship, while man remains passive due to his or her lifeless spiritual condition.
} 
confession of faith, a commentary by one of its authors is no longer of importance. What mattered to the Dutch Reformed Church was, above all, the agreed-on contents of the Catechism rather than the way Ursinus interpreted these contents. R.A. Muller also claims that the non-revision of the contents of Confessio Belgica by the Synod of Dort is evidence that the synod saw no need to refine specific points of this document (e.g., Article 16, on Divine election) that would refute the views of Arminius' followers, known as Remonstrants. William den Boer replies that what made this kind of revision unnecessary was the Canons of Dort, being a refutation of the Remonstrance ${ }^{6}$ of $1610 .^{7}$ Thus, as can be seen, we are dealing with quite a complex problem. Nevertheless, when attempting to evaluate Arminian theology, what I will consider as the context is those interpretations that eventually dominated the Reformed tradition and that remain consistent with the teaching of John Calvin and his followers. I shall also propose that the following theological themes be regarded as essential to the term "Reformed": God's sovereignty and glory, covenant theology, monergistic soteriology, and predestination. These particular points of Arminius' teaching will be analysed in an attempt to answer the question posed in the title of the paper.

\section{GOD'S SOVEREIGNTY AND GLORY}

There is no denying that, for the Leiden scholar, God was a sovereign being. This means everything is subject to God, as $\mathrm{He}$ is the one who has power over His creation. Two fragments of Declaratio Sententiae should be cited here:

I consider Divine Providence to be the loving, continual, and omnipresent supervision, whereby [God] takes universal care of the whole world, particularly of all creatures without exception, in order to guide and protect them in their essence, properties, acts, and feelings according to what is right and what is appropriate for them, for the glory of His name. and for the salvation of believers. ${ }^{8}$

\footnotetext{
${ }^{6}$ Remonstrance is a document published on 14 January 1610, presented to the States General of the Netherlands by Arminius' followers, containing, among other things, Remonstrants' five-point confession of faith.

${ }^{7}$ Cf. William den BoER, “'Cum delectu': Jacob Arminius's (1559-1609) Praise for and Critique of Calvin and His Theology," Church History and Religious Culture 91 (2011): 82-85.

8 "Providentiam Dei statuo esse solicitum, continuum et ubique praesentem Dei intuitum, secundum quem universe quidem curat totum mundum, particulariter vero omnes universe
} 
[...] Nothing in the world happens by chance. Apart from that, I regard the free will and even the acts of the rational creation as subject to Divine Providence; this means nothing can be done without God's will [...]. ${ }^{9}$

The above quotations are evidence that the author believed in the dependence of creation on the Creator. The Dutch reformer was deeply convinced of the providential management of the world by the Absolute. God guides everything to such an extent that even the free will of rational beings is subject to His will without the slightest exception. A clearer testimony to Arminius' affirmation of God's sovereignty could hardly be expected. Calvin also wrote that "not only heaven and earth as well as inanimate beings, but also human intentions and wills are governed by His Providence to go the right way towards the destined goal" ${ }^{\prime \prime}$. Still, the issue of God's sovereignty or dominance over the world was discussed in greater detail in Arminius's twenty-seventh private disputation, titled "De Dominio Dei" ("On the Dominion of God"). It is necessary to devote attention to this disputation because it contains certain nuances that will enable us to better understand the specificity of the Leiden scholar's thought. The Dutch reformer emphasizes that supremacy over creation is the Creator's right. All beings created to live are God's property, which means He is free to do with them whatever is right and whatever the Creator-creation relationship allows. ${ }^{11}$ Even this makes it clear that, according to Arminius, God does not have the possibility doing literally everything with people. Namely, God could never guide or use man in such a way as to introduce sin into the world through him or her in order to manifest His glory by condemning and forgiving the $\sin ^{12}$ "[God cannot] do [with His creature] what he is able to do thanks to His absolute power, namely: [He cannot] eternally condemn or

creaturas, nulla earum excepta; horsum, ut eas in essentia sua, qualitatibus, actionibus et passionibus suis conservet et gubernet, prout se decet atque ipsis congruum est, ad laudem sui nominis et salutem credentium." Jacob ARMinIUs, "Declaratio sententiae Iacobi Arminii," in Opera Theologica Iacobi Arminii (Leiden: Godefridum Basson, 1629), 121.

9 “....] quodque nihil plane calua ut fortuito contingat. Imo vero etiam Providentiae Dei subiicio liberum arbitrium ipsos que rationalis creatura actus; sic ut nihil fiat sine voluntate illius [...]" Ibid.

10 "Unde eius providentia non caelum modo ac terram, et creaturas inanimatas, sed hominum etiam consilia et voluntates gubernari sic afferimus, ut ad destinatum ab eas copum recta ferantur"; John Calvin, Institutio Christianae Religionis, I, XVI, 8 (Geneva: Oliua Roberti Stephani, 1559), 64.

${ }^{11}$ Cf. Jacob ARminIus, "Disputationes Privatae," XXVII, 1-2, in Opera Theologica Iacobi Arminii (Leiden: Godefridum Basson, 1629), 371.

${ }^{12}$ Cf. Jacob ArminIus, "Disputationes Privatae," XXVII, 3, in Opera Theologica Iacobi Arminii (Leiden: Godefridum Basson, 1629), 371. 
destroy without sin [having been committed by that creature]." ${ }^{13}$ A special kind of dominance is dominance over rational beings, such as humans. The Leiden professor distinguished two possible ways of exercising this hegemony. He referred to one of them as "despotic" (despotiche) and to the other one as "royal" (basiliche) or "patriarchal" (patriche). The former is based on the assumption that the Creator can manage His creatures without any intention of giving the good that could be salutary for them. The latter type presupposes that, in his exercise of power over people, God has their good in view. ${ }^{14}$ It is not difficult to guess that Arminius leaned towards the latter model of God's sovereignty. In some sense, this distinguishes Arminius from Calvin, especially when it comes to the sovereign God's relationship to evil. Arminius believed that the reformer from Geneva and his successor Theodore Beza, whose theology student he was, accidentally made God the author of sin (auctor peccatum). What is noteworthy is the rejection of Calvin's conclusion that humans forever damned cannot justify their sins with the fact that God, in his sovereignty and Providence, decreed their fall-not because this was not the Creator's intention, but quite the contrary: because their fallen condition was, after all, God's ordinatio, as Calvin would say. Divine judgments are indisputable, since they are always right (aequitas), and even though they sometimes seem to be unjust, this is only due to the limited human cognitive abilities; this means no eternally damned sinner has anything to justify their sins. ${ }^{15}$ Arguments of this kind did not convince the Leiden scholar, who had a different opinion on the intelligibility of God's justice. Iustitia Dei, according to Arminius, is not so highly inaccessible to our cognition as Calvin claimed it was, because God decided to reveal Himself. The Revelation provides the believer with knowledge about justice, including God's justice. This means the Creator cannot possibly act the way Calvin and Beza taught he did. An extremely important topic in Arminius' theology should be mentioned at here: duplex amor Dei. It meant that, in the first place, the Creator loves justice, which is followed by love for humans. All God's actions with regard to rational creatures are inspired precisely by this primary love. According to Arminius, the concept of iustitia Dei should

\footnotetext{
13 "De illa faciendi quidquid secundum absolutam suam potentiam de illa facere potest, scilicet, aeternum punire vel affligere citra peccatum." Ibid. I deliberately cite examples concerning sin, salvation, and damnation because they will be relevant further in the article, in sections devoted to the issues of covenant theology and predestination.

${ }^{14}$ Cf. ibid., XXVII, 4, in Opera Theologica Iacobi Arminii, 371.

${ }^{15}$ Cf. CAlvin, Institutio Christianae Religionis, III, XXIII, 9, p. 349.
} 
be understood as "permanent disposition of the will to give what is due to others." 16 This shows a fundamental difference between the Dutch reformer and the master from Geneva. The former thinker was strongly inspired by the Thomist tradition, marked by intellectualism, whereas the latter seems to have had a voluntaristic orientation, associated above all with late medieval Augustinian theology ${ }^{17}$.

According to what the Leiden professor wrote, God's power puts into practice what God's will, guided by God's knowledge (scientia), decrees. ${ }^{18}$ Therefore, he would never have agreed with Calvin's words that "His pure will" is "the highest form of justice." ${ }^{19}$ As can be seen, both authors were convinced of the Creator's sovereignty, but they approached this issue differently due to their basic assumptions. The greatest difference was the fact that in the case of Arminius all actions of the Absolute were subject to His nature and His perfect knowledge of good. ${ }^{20}$ Calvin, by contrast, seemed to be more focused on God's will itself, which is a fairly characteristic feature of the Reformed way of thinking about the relationship between the Creator and His creation. It is therefore evident that we are dealing with agreement in a general sense, while dissonance appears at deeper levels of theology, which have significant influence on the flavour of the two authors' teaching.

Roger E. Olson presents the Leiden professor as a man whose thought is fairly strongly rooted in the Reformed tradition due to his emphasis on the issues of God's glory and covenant theology. ${ }^{21}$ At this stage of discussion I will examine the first of the features of Arminian thought listed by R.E. Olson,

\footnotetext{
16 "Iustitia Dei [...] perpetua est et constans voluntas suum cuique tribuendi"; ARMINIUS, "Declaratio Sententiae," in Opera Theologica Iacobi Arminii, 106.

${ }^{17} \mathrm{Cf}$. den BoER, "“Cum delectu'," 75-82.

${ }^{18}$ Cf. Arminius, "Disputationes Publicae," IV 79, p. 229. This reflects the order of God's actions postulated by Thomas Aquinas himself—cf. Summa Theologiae, I', q. 25, a. 1, ad. 4.

19 "Tametsi iustae Dei vindictae vasa sunt reprobi, rursum electi vasa misericordiae, causa tamen discriminis non alia in Deo quaerenda est quam mera eius voluntas, quae summa est iustitiae regula"; John CALvin, "Tractatus Theologici Minores. Tomus Quintus," in Ioannis Calvini opera quae supersunt omnia, ed. Edouard Cunitz, Johann-Wilhelm Baum, and Eduard Wilhelm Eugen Reuss, vol. IX (Corpus Reformatorum, vol. XXXVII; Brunsvigae: C.A. Schwetschke et Filium, 1870), col. 713

${ }^{20}$ D. Stephen Long additionally observes that Arminius placed strong emphasis on God's selfgiving goodness imparted to creation. Cf. D. Stephen Long, The Perfectly Simple Triune God. Aquinas and His Legacy (Minneapolis: Fortress Press, 2016), 158.

${ }^{21}$ Cf. Roger E. OLson, Arminian Theology. Myths and Realities (Downers Grove: InterVarsity Press, 2006), 51.
} 
and further in the article a separate section will be devoted to covenant theology.

Arminius defined God's glory as follows: "[God's] glory is all-surpassing perfection that [God] manifests in various ways through external acts." 22 This means the Creator is above every being other than Himself. No one and nothing can equal Him. What is characteristic of Reformed thought is the view of God's glory as the ultimate purpose of His salvific designs. Arminius' opinion was the same, as he wrote:

Let us bear [this issue] in mind: for what purpose did [God] bring the fallen back to the state of integrity, reconcile sinners with Himself, and restore enemies to His favour? We should conclude that [all this was done] so that we can partake in eternal salvation and worship [Him] forever. ${ }^{23}$

[The aim] is entirely divine-God's glory and man's eternal salvation. What could be more appropriate than returning to the One in whom everything has its origin? What could be more consistent with Divine wisdom, goodness, and might than the restoration of man-whom God created and who is lost through his own fault — to the state of integrity and making him a participant in God's bliss? [...] This is where God's glory shines the most brightly. ${ }^{24}$

The above passages very distinctly show what tradition Jacob Arminius belonged to. On this issue, he remains consistent with the Synod of Dort, whose decisions clearly say that:

God has decreed to give to Christ to be saved by Him, and effectually to call and draw them to His communion by His Word and Spirit; to bestow upon them true faith, justification, and sanctification; and having powerfully preserved them in the fellowship of His Son, finally to glorify them for the demonstration of His mercy, and for the praise of the riches of His glorious grace; as it is written. ${ }^{25}$

22 "Gloria est excellentia supra omnia, quam ipse actibus externis variae manifestam facit." Jacobus ARMINIUS, “Disputationes Privatae," XXIII, 5, in Opera Theologica Iacobi Arminii (Leiden: Godefridum Basson, 1629), 363.

23 "Veniat in mentem, quem in finem lapsos restituerit in integrum, peccatores sibi reconcilia verit, inimicos in gratiam receperit; et comperiemus hunc esse, ut salutis aeternae participes essemus, eique in seculum laudes diceremus." Arminius, "Oratio Secunda. De Authore et Fine Theologiae," in Opera Theologica Iacobi Arminii, 55.

24 "Ille totus est divinus, Dei gloria et salus hominis aeterna. Quid aequius, quam ut omnia eo referantur unde initium duxerunt? Quid Dei sapientiae, bonitati, potentiae, magis conveniens, quam ut hominem ab ipso creatum, sed sua culpa perditum, in integrum restituat et divinae beatitatis participem faciat? [...] qua ipsa in re Dei Gloria copiossisime elucet." ARminius, "Oratio Tertia. De Certitudine S. Sanctae Theologiae," in Opera Theologica Iacobi Arminii, 61-62.

${ }^{25}$ The Canons of Dort, cap. 1 art. 7, https://chapellibrary.org:8443/pdf/books/codo.pdf (accessed: 20.01.2018). 
The Leiden scholar wrote a very similar thing in his fifteenth public disputation, titled "On Divine Predestination" (“De Divina Praedestinatione"):

Thus, in essence, predestination is a decree of God's delight in Christ, by which, from eternity, [He] resolved to justify, accept, and bestow eternal life on the faithful - whose gift of faith He decreed-for the exaltation of His glorious grace. ${ }^{26}$

These quotations are so clear that they require no further comment. Arminius was focused on God's glory which is the ultimate purpose of the Creator's actions to the same degree as the remaining Reformed theologians. $\mathrm{He}$ is therefore a fully orthodox Calvinist in this respect.

\section{COVENANT THEOLOGY}

Undoubtedly, what is known as "covenant theology" has been vibrantly alive in the Reformed tradition to this day. It can be said that "covenant" is the basic category that Calvin and other Reformed theologians use to describe the God-man relationship. ${ }^{27}$ Covenant theology was systematically developed in the $17^{\text {th }}$ century, but its "non-systematic" form can be found as early as the writings of the great reformer from Geneva. ${ }^{28}$ The basic distinction

\footnotetext{
26 "Praedestinatio itaque, ad rem quod attinet ipsam, est Decretum Beneplaciti Dei in Christo, quo apud se ab aeterno statuit fideles, quos fide donare decrevit, iustificare, adoptare, et vita aeterna donare ad laudem gloriosae gratiae suae." ARMINIUS, "Disputatione spublicae," XV, 2, p. 283. Elsewhere, besides "laus gloriosae gratiae suae" ("the exaltation of His glorious grace"), the author adds "[...] declarationem iustitiae suae" ("the declaration of His [Divine] justice"); ARMINIUS, "Disputationes Privatae," XL, 2, in Opera Theologica Iacobi Arminii, 390.

${ }^{27}$ One of the available introductions to Reformed theology is: Michael HorTON, Introducing Covenant Theology (Grand Rapids, MI: Baker Books, 2006). There are also studies approaching this issue from the perspective of biblical and historical theology. See e.g., J. Mark BEACH, "Calvin and the Dual Aspect of Covenant Membership: Galatians 3:15-22 - the Meaning of "the seed' is Christ"-and Other Key Texts," Mid-America Journal of Theology 20 (2009): 49-73; Steven R. CoxHEAD, "Deuteronomy 30:11-14 as a Prophecy of the New Covenant in Christ," Westminster Theological Journal 68 (2006): 305-320; Breno MACEDO, "Covenant Theology in the Thought of John Calvin. From the Covenant of Works to the Abrahamic Covenant," Fides Reformata 20 (2015): 89-105; Richard A. Muller, "Covenant and Conscience in English Reformed Theology. Three Variations on a $17^{\text {th }}$ Century Theme," Westminster Theological Journal 42 (1980): 308-334; MulLER, "The Covenant of Works and the Stability of Divine Law in Seventeenth-Century Reformed Orthodoxy: A Study in the Theology of Herman Witsius and Wilhelmus a Brakel," Calvin Theological Journal 29 (1994): 75-101; O. PALMER ROBERTSOn, The Christ of the Covenants (Philipsburg, NJ: P\&R Publishing, 1980).

${ }^{28}$ Cf. MACEDO, "Covenant Theology," 89-105.
} 
in the Reformed theology of Arminius' times was the division into the covenant of nature (foedus nature) or the covenant of works (foedus operum) ${ }^{29}$ and the covenant of evangelical grace (foedus gratiae evangelicum) ${ }^{30}$ The first covenant was made at creation and was based on adherence to the natural law (lex naturalis) implanted in man. Man was capable of full adherence to it because he was in a state of original integrity (status integritatis, status originalis), which means he had all the natural and supernatural gifts. $\mathrm{He}$ was just and had full knowledge of God, with whom he lived in deep intimacy. The fall of the human being led to the breach of the covenant of works and left its characteristic mark on human nature. Man lost the original justice (privatio iustitiae originalis), which involved the loss of perfect knowledge of good and the infection of every part of human nature by sin; he deprived himself of communion with the Creator (privatio communionis cum Deo), which gave rise to sinful inclinations. Therefore, God decided to proclaim a new covenant, independent of human ability to fulfil it. This was the promise of salvation given to the sinful mankind, whose content was expressed in what is known as the protoevangelium (Gen. 3:15). Reformed theologians have sometimes called it a unilateral covenant (foedus monopleuron), because its initiator and guarantor is God Himself. This covenant is one as regard the substance, but there have been several applications of it in the history of salvation. As a result, foedus gratiae evangelicum took various forms, such as the Abrahamic Covenant or the Sinaitic Covenant, but its most complete form came into being with Christ and continues to the present day.

After this brief introduction to Reformed covenant theology, it is necessary to analyse Arminius' thought and find out whether or not he remained faithful to his tradition on this issue.

In his reflection on the Creator-creation relationship, the Leiden professor distinguished legal theology (legalis theologia) and Christian (evangelical) theology (christiana theologia, evangelica theologia). The subject matter of legal theology is God, who is the creator of the world and man. It speaks of a relationship between God and creation untarnished by sin. This state of affairs could continue until sin appeared in the history of the world. It should be added that, to Arminius, man in the prelapsarian condition was

\footnotetext{
${ }^{29} \mathrm{Cf}$. entries for foedus naturae and foedus operum, in Richard A. MuLLER, Dictionary of Latin and Greek Theological Terms. Drawn Principally from Protestant Scholastic Theology (Grand Rapids, MI: Baker Academic, 1985), 122.

${ }^{30}$ Cf. foedus gratiae, ibid., 120-121.
} 
a being in the unfallen state of grace rather than pure nature. Evangelical theology differs from legal in that it is focused on God the Saviour, and its main subject is God and His Christ. It speaks of the relationship between the Creator and man, created, fallen, and redeemed by Christ. It is professed in the Church, and so it is professed by those who acknowledge their dependence on the Creator in their existence, who acknowledge the need to be redeemed, and who are aware that the world was saved thanks to the Incarnation, Death, Resurrection, and Exaltation of Jesus Christ. It is a theology about the current world, which is between the Incarnation and the Eschaton. ${ }^{31}$ It is not difficult to guess that Arminius is referring to foedus operum and foedus gratiae evangelicum here. "Thus, the author of legal theology is God, while the author of evangelical theology is God and His Christ or God in Christ and through Christ." 32 It can be clearly seen that, to Arminius, the new covenant (evangelical theology) is associated with the idea of priestly mediation in God's salvific dialogue with man.

The division into legal and evangelical theology allowed the Leiden scholar to link and distinguish the concepts of creation and redemption. It became his starting point for building a consistent biblical theology of grace. This kind of perspective interprets Christianity not only as focused on the eternal, ahistorical truths. The Christian faith also has a narrative dimension, part of which is the history of the creation and salvation of mankind. In Arminian theology, God is seen as personal and intensely involved in the fate of the world. The relationship between the Creator and creation is not one-directional only (God acts, man responds). It is bidirectional, and its bidirectionality consists in the fact that God can respond to human actions as well. In the context of the Leiden professor's covenant theology, the execution of the plan of salvation can be mentioned here. This execution would not have taken place if man had not sinned. Sin is most certainly something that the Creator cannot have "created"; it is, more accurately, the outcome of human abuse of the gift of freedom. ${ }^{33}$ Instead of meting out just punishment,

\footnotetext{
${ }^{31}$ Cf. William Gene WitT, "Creation, Redemption and Grace in the Theology of Jacob Arminius," PhD diss. (University of Notre Dame, 1993), 215-216. See ARminius, "Oratio Prima. De Obiecto Theologiae," in Opera Theologica Iacobi Arminii, 32-41; ARMinius, "Oratio Secunda. De Authore et Fine Theologiae," in Opera Theologica Iacobi Arminii, 42-49.

32 "Legalis itaque Theologia Author est Deus, Evangelica, Deus et Christus eius, vel Deus in Christo et per Christum"; ARMinius, "Oratio Secunda," 42.

${ }^{33}$ CF. Jacob Arminius, "Disputationes Publicae," VII, 4-13, in Opera Theologica Iacobi Arminii (Leiden: Godefridum Basson, 1629), 239-241; ARminius, "Disputationes Privatae," XXX, 3-6, in Opera Theologica Iacobi Arminii (Leiden: Godefridum Basson, 1629), 375-376.
} 
God responds to Adam's fall with a promise of salvation due to the two-way responsive relationship of love that links Him with humans. The covenant of nature (legal theology) and the covenant of grace (evangelical theology) are therefore real covenants between the Divine and human parties. In other words, Arminian covenant theology speaks of a God who takes salvific initiative and enables man to participate in salvation. ${ }^{34}$

Jacob Arminius's covenant theology is consistent with Reformed Protestantism. The scholar shows tendencies characteristic of what is known as early orthodoxy, which presented the God-man relationship in terms of "covenant," speaking of actual (works-based) foedus naturae and evangelical foedus gratiae. As far as this issue is concerned, he is a fully Reformed theologian.

\section{SOTERIOLOGY (MONERGISM)}

In this section I am not going to discuss soteriology in a detailed manner because the subject is too broad. The discussion will be limited to the relationship between the Saviour and the saved, which is usually explained in two ways in Christian theology: monergistic and synergistic. According to the former view, God is the only active and determining reality in the work of salvation. The latter option maintains that there exists free human participation to salvation and that a kind of cooperation of will with God's grace takes place. ${ }^{35}$ In the Reformed tradition synergism has a negative connotation to this day due to the ancient heresies of Pelagianism and Semipelagianism. Calvin, who was Augustine's follower, adopted a monergistic view of salvation. ${ }^{36}$ It is in this context that Arminius' views should be analysed.

The Leiden professor adopted Luther's and Calvin's pessimistic anthropology; he also believed in the necessity and prevenience of grace. Before man makes a "step of faith" towards God, he must be endowed with grace that will open this possibility for him. ${ }^{37}$ Still, a question arises whether the

\footnotetext{
${ }^{34}$ Cf. WiTt, "Creation, Redemption and Grace," 215-222.

${ }^{35}$ Cf. Jerzy BuXakowski, Laska Ducha Świętego i człowiek (Pelplin: Bernardinum, 2007), 133; Olson, Arminian Theology, 17-19; OLson, Historia teologii chrześcijańskiej, 124, 269-270, 317.

${ }^{36}$ Cf. e.g., Rafał Marcin LeSZCZYŃsKi, Ojcowie Reformacji i filozoficzne watki ich teologii (Warsaw: Wydawnictwo „Nowe Spojrzenia,” 2010), 129-132; Olson, Historia teologii, 438-440.

${ }^{37}$ Cf. Damian DorockI, "Nieograniczone odkupienie i odparta łaska. Klasyczny arminianizm we współczesnej teologii ewangelikalnej,” Rocznik Teologiczny (ChAT) 58 (2016): 39-40.
} 
Dutch reformer believed that the grace enabling conversion was a particular grace (gratia particularis), reserved for the elect, and whether, consequently, he believed that this grace was irresistible (gratia irresistibilis). If so, Arminius would have been a monergist and an advocate of theological determinism. However, it was Arminius who wrote that "grace is not an irresistible force." ${ }^{38}$ How, then, did he resolve the tension between man's inability to do anything for his salvation and the sovereignty as well as primacy of God's grace? Arminius resorted to Augustine's and Aquinas' distinction between prevenient grace (gratia praeveniens) and subsequent grace (gratia subsequens). Prevenient grace, as the name suggests, precedes the act of human will, before man returns to God. It is the miraculous influence of the Holy Spirit thanks to which a sinner is able for the first time to voluntarily respond to the proclaimed Gospel. ${ }^{39}$ What is interesting, the Leiden scholar also wrote the following words: "I believe, in accordance with the Scriptures, that many oppose the Holy Spirit and reject the grace that is given to them." ${ }^{40}$ According to Arminius, every person receives gratia praeveniens, when God's word is announced to him or her, but not everyone inevitably has to submit to the Holy Spirit. ${ }^{41}$ In this model, God wants to save us with grace but does not want to save us without our voluntary participation. Therefore, it is not until after man's positive response to God's call that a complete actualization of the gifts ensured by Christ's sacrifice occurs (gratia subsequens). ${ }^{42}$ What is important, faith does not function as something to give a person credit for: "When speaking of believers, we do not refer to those who come to believe through their own accomplishments or efforts but to those who come to believe in Christ thanks to God's gracious and extraordinary goodness." ${ }^{, 43}$ Salvation, according to Arminius, is given under the conditions of faith in Christ, as this follows from the Bible. ${ }^{44}$

\footnotetext{
38 "[...] gratia est non vis irresistibilis"; ARMINIUS, "Articuli Nonnulli Diligenti Examine Perpendendi," in Opera Theologica Iacobi Arminii, 959.

${ }^{39}$ Cf. DoRocki, "Nieograniczone odkupienie," 40.

40 "[...] juxta Scripturas credo, quod multi Spiritui S. resistunt, et gratiam oblatam repellunt." ARminius, "Declaratio Sententiae," in Opera Theologica Iacobi Arminii, 122.

${ }^{41}$ On this point, Arminius seems to agree with the Lutheran orthodoxy, which acknowledges that the grace thanks to which a person converts is a universal (gratia universalis) and serious grace (gratia seria).

${ }^{42}$ Cf. DoROCKI, "Nieograniczone odkupienie," 40.

43 "Fideles autem dicimus non qui tales proptiis meritis aut viribus erant futuri, sed qui Dei beneficio gratuito et peculiari in Christum erant credituri." ARMinIUs, "Disputationes Publicae," XV, 7, in Opera theologica Iacobi Arminii, 284.

44 "[...] fidem prius esse conditionem a Deo requisitam, ut praestetur ab eo qui salvabitur, quam medium salutis obtinendae." ARMINIUS, "Apologia adversus Articulos XXXI," art. IV, in Opera
} 
This does not mean that he was a "theologian of free will"; as far as this issue is concerned, it is more accurate to call him a "theologian of grace," since non-free will experiences salvific liberation thanks to grace. Therefore, contemporary Arminians say that the Leiden professor taught about "freed will." "4lthough human free will does not play any role in salvation without prevenient grace, it can be said that we are dealing here with a model of man's limited cooperation with God. This aspect of the Leiden professor's teaching is consistent with the Christian tradition that preceded it. ${ }^{46}$

It should also be explained what induced Arminius to place emphasis on the free response of a person inspired by the Holy Spirit. Firstly, if people are subject to external determination, their choices cannot be free. This leads to blaming God Himself for evil and sin, which is a blasphemy. Secondly, freedom is a necessary element in the process of salvation. Grace refines rather than supersedes nature. This means it is not an irresistible force and can be rejected. Although free will and grace go "hand in hand," the Leiden scholar's object of interest was, above all, natura gratiae Dei. Thirdly, the affirmation of human freedom supports the truth about the mutual nature of the relationship between the Creator and creation, which is attested by the Scripture. God's justice, grace, and relational love determine this human freedom, and therefore there is no place in the Dutch reformer's thought for the anthropocentrism that he has been accused of in the course of history. ${ }^{47}$

The Leiden theologian's understanding of the relationship between grace and free will significantly diverged from the classic monergistic model that dominates in Reformed Protestantism. It must therefore be concluded that a kind of departure from the Calvinist tradition took place.

\section{PREDESTINATION}

The classic Calvinist perspective on the issue of Divine predestination is best expressed in the following words:

\footnotetext{
Theologica Iacobi Arminii, 140; Arminius, "Iacobi Armini amica collatio cum D. Francisco Iunio de Praedestinatione," in Opera Theologica Iacobi Arminii, 462.

${ }^{45}$ Cf. Olson, Arminian Theology, 142, 146, 155, 163-164; Keith D. STAnglin and Thomas H. MCCALL, Jacob Arminius. Theologian of Grace (New York: Oxford University Press, 2012), 158.

${ }^{46}$ Cf. Stanglin and McCall, Jacob Arminius. Theologian of Grace, 158.

${ }^{47}$ Ibid., 163-164.
} 
By predestination we mean the eternal decree of God, by which he determined with himself whatever he wished to happen with regard to every man. All are not created on equal terms, but some are preordained to eternal life, others to eternal damnation; and, accordingly, as each has been created for one or other of these ends, we say that he has been predestinated to life or to death. ${ }^{48}$

The above quotation from Calvin's Institutions summarizes what is known as the doctrine of unconditional predestination. Due to the sovereignty of God's will and due to human powerlessness, man's ultimate fate is decided on by the Creator, not by man himself. What God determined before ages will be inevitably fulfilled in every person's life. Calvin respected mystery and realized that it would not be possible to answer all the questions which this doctrine provokes. What the reformer from Geneva did not say, subsequent Reformed theologians attempted to probe. They asked, above all, about the logical order of God's decrees (ordo decretorum Dei) - that is, about what God decided first: to save and damn or to create. The most popular theories proposed in Arminius's times as solutions to this problem were supralapsarianism and infralapsarianism. According to the former, God determined the ultimate fate first, and only then did he decide to create people. According to the latter, the order was reverse-God first decided to create man and allow the fall and only then decided that he would elect some people, leaving the remaining ones in $\sin .{ }^{49}$ The common denominator of these interpretations is that God's election is unconditional. In the Calvinist perspective, gracious salvation and damnation are not conditioned by anything except God's will, which determined what was to happen.

In the case of Arminius, it is legitimate to speak of conditional predestination. ${ }^{50}$ Predestination is also eternal, but it is based on God's foreknowledge (praescientia Dei) of the free acceptance or non-acceptance of

\footnotetext{
${ }^{48}$ John CALVIN, "Nauka religii chrześcijańskiej,” III, XXI, 5, trans. Irmina Lichońska, in Myśl filozoficzno-religijna Reformacji XVI wieku, ed. Lech Szczucki (Warsaw: PWN, 1972), 381; English text cited from: John CALvin, The Institutes of the Christian Religion, trans. Henry Beveridge (Grand Rapids, MI: Christian Classics Ethereal Library, 2002), 568, The NTSLibrary (Online Christian Library of Virtual Theological Resources), http://www.ntslibrary.com/PDF\%20Books/Calvin \%20Institutes\%20of\%20Christian\%20Religion.pdf (accessed: 20.01.2018).

${ }^{49}$ Cf. Olson, Historia teologii, 489-491; Robert E. Picirilli, Grace, Faith, Free Will. Contrasting Views of Salvation: Calvinism \& Arminianism (Nashville, TN: Randall House Publications, 2002), 10, 32-33; praedestinatio, in MulleR, Dictionary of Latin and Greek, 234-235; supra lapsum, ibid., 292.

${ }^{50}$ In the present section it is impossible to present the Arminian perspective on predestination exhaustively. For a more extensive discussion, the reader is referred to: Damian DorockI, "Doktryna predestynacji w teologii Jakuba Arminiusza," Teologia i Człowiek 35 (2016): 107-124.
} 
his grace ${ }^{51}$ However, before the Leiden professor voiced his position on electio and reprobatio Dei with regard to individuals, he strongly emphasized that the Creator's first decrees were those instituting the Son of God as Mediator and Redeemer and regarding the salvation of believers and the damnation of nonbelievers. Next, God decreed decided that the means necessary for salvation would be provided ${ }^{52}$ - namely, the word and the Spirit. ${ }^{53}$ Only at the end of the Arminian ordo decretorum Dei is there a decree concerning the predestination of particular individuals, which the Dutch reformer phrased as follows:

These decrees are followed by the fourth order, by which [God] decides to save and damn particular individuals. This decree is based on Divine foreknowledge, thanks to which God knows, from eternity, who-given the appropriate means for repentance and faith-will believe thanks to His prevenient grace and persevere thanks to subsequent grace, as well as who will not believe and who will not persevere. ${ }^{54}$

In this perspective, human will has been embedded in the reality of Divine predestination. This means that God's grace does not consist, as it were, in "physically setting the non-free will into motion" as a result of God's irrevocable decree, but rather in opening up for this will a unique possibility of choosing the highest good: namely, God as revealed in Christ. Of course, the Creator's knowledge about the future is certain, and so election is certain too. In Arminius's theology there is, however, a place for freely saying "yes" to God, whose only raison d'être is the gratuitously given grace liberating the human soul.

The theory of conditional predestination seems to be what distinguishes Arminius the most strongly from Calvin. It was this particular aspect of Arminius's teaching that became the basis for the opinions that he was not a Reformed theologian. They are somewhat exaggerated, given that predestination was never a central doctrine in the thought of the reformer from Geneva. In fact, it did not become important until after his death, when

\footnotetext{
${ }^{51}$ Cf. ibid., 120.

${ }^{52}$ Cf. ARminius, "Declaratio Sententiae," in Opera Theologica Iacobi Arminii, 119.

${ }^{53}$ Cf. ARminius, "Disputationes Privatae," XLI, in Opera Theologica Iacobi Arminii, 391-392.

54 "Hinc sequi quartum decretum, quo decrevit singulares et certas quasdam personas salvare et damnare. Atque hoc decretum praescientia Dei innititur, qua ab aeterno scivit, quinam iuxta eiusce modi administrationem mediorum ad conversionem et fidem idoneorum, ex praeveniente ipsius gratia credituri erant, et ex subsequente gratia perseveraturi; quive vero etiam non erant credituri et perseveraturi.” ARMinIUS, “Declaratio Sententiae," in Opera Theologica Iacobi Arminii, 119.
} 
Reformed scholastics debated on the already mentioned ordo decretorum Dei. Nevertheless, the Leiden scholar broke with the Augustinian view of Divine predestination, so well settled in the Reformed tradition, which makes it legitimate to conclude that, in this respect, Arminius did not remain faithful to mainstream Calvinism.

\section{CONCLUSION}

In the light of what has been established above, it should be concluded that Arminius was a theologian only partly adhering to his theological tradition. In his case, we are not, of course, dealing with total departure from Reformed Protestantism. The Leiden scholar's theological language and views in the fields of Christology, ecclesiology, sacramentology, or eschatology were absolutely Calvinistic. ${ }^{55}$ They are not, however, commonly associated with Calvinism, which is why they were not chosen as the object of analysis in the present paper. As far as the essential motives of Reformed thought are concerned, some may be surprised by how strongly Arminius stressed God's sovereignty over creation. For him, this truth was undeniable. The situation was the same with Divine glory as the ultimate end of God's salvific designs. Also in line with the classic Reformed tradition was the Dutch reformer's covenant theology. These elements of Arminian teaching undoubtedly reflected the truly Reformed spirit of his thought. On the other hand, serious differences have been observed between Arminius and Calvin as well as later Calvinist doctrine. It is, after all, impossible to reconcile unconditional predestination with conditional predestination or irresistible grace with resistible grace. Indeed, the Leiden professor allowed man to say "yes" or "no" to God. He therefore was, to some extent, a synergist-although he never forgot about human incapacity to freely choose salvation without grace prevenient to this choice. In other words, in his soteriology, Arminius proclaimed the radical primacy of gratia Dei. He never said that salvation was a fruit of God's cooperation with man, either. It is, more accurately, God's work which takes place in the life of an individual person thanks to resistible grace enlightening the mind and liberating the will. In my opinion, this difference of views was rooted in the fundamental Thomistic assumption of Arminius's theology: his teaching on God's self-giving goodness. Of all

\footnotetext{
${ }^{55}$ Cf. Stanglin and MCCALl, Jacob Arminius, 202.
} 
Reformed theologians, it was the Leiden scholar who stressed it the most strongly and did not modify it in any way. This means that-in this aspect of his teaching-he was a genuine Thomist. ${ }^{56}$ In this perspective, theology was, to Arminius, a practical science, a means for unification with the Creator, a science that - through the theology of creation and soteriology-was supposed to lead to the conclusion that God is the highest good (summum bonum) ${ }^{57}$ For these reasons, it was not possible for the Dutch reformer to be a one-hundred-percent Calvinist, because in his opinion the Calvinistic way of thinking did not fully convey the truth about the goodness communicated by God in the act of creation and redemption. This explains why Jacob Arminius partly "forsook his allegiance" to the Reformed tradition. I would therefore call him an "idiosyncratic" or "critical" Reformed theologian.

\section{BIBLIOGRAPHY}

ARminIUS Jacob. “Apologia Adversus Articulos XXXI.” In Opera Theologica Iacobi Arminii, 134183. Leiden: Godefridum Basson, 1629.

ARminius, Jacob. “Articuli Nonnulli Diligenti Examine Perpendendi." In Opera Theologica Iacobi Arminii, 948-966. Leiden: Godefridum Basson, 1629.

Arminius, Jacob. "Declaratio Sententiae Iacobi Arminii.” In Opera Theologica Iacobi Arminii, 91133. Leiden: Godefridum Basson, 1629.

Arminius, Jacob. “Disputationes Privatae.” In Opera Theologica Iacobi Arminii, 339-444. Leiden: Godefridum Basson, 1629.

Arminius, Jacob. "Disputationes Publicae." In Opera Theologica Iacobi Arminii, 197-338. Leiden: Godefridum Basson, 1629.

Arminius, Jacob. “Oratio Prima. De Obiecto Theologiae.” In Opera Theologica Iacobi Arminii, 2641. Leiden: Godefridum Basson, 1629.

Arminius, Jacob. "Oratio Secunda. De Authore et Fine Theologiae." In Opera Theologica Iacobi Arminii, 41-55. Leiden: Godefridum Basson, 1629.

Arminius, Jacob. “Oratio Tertia. De Certitudine S. Sanctae Theologiae.” In Opera Theologica Iacobi Arminii, 56-71. Leiden: Godefridum Basson, 1629.

Arminius, Jacobus. "Iacobi Armini Amica Collatio cum D. Francisco Iunio De Praedestinatione." In Opera Theologica Iacobi Arminii, 458-619. Leiden: Godefridum Basson, 1629.

BANGS, Carl. “Arminius and the Reformation.” Church History 30 (1961): 155-170.

BANGS, Carl. "Dutch Theology, Trade and War: 1590-1610.” Church History 39 (1970): 470-482.

\footnotetext{
${ }^{56}$ Cf. Long, The Perfectly Simple, 158.

${ }^{57}$ Cf. Richard A. Muller, "Arminius and Scholastic Tradition," Calvin Theological Journal 24 (1989): 273-274.
} 
BAngs, Carl. Arminius. The Study in the Dutch Reformation. Eugene, OR: Wipf \& Stock Publishers, 1998.

BAngs, Carl. Review of God, Creation and Providence in the Thought of Jacob Arminius. Sources and Directions of Scholastic Protestantism in the Era of Early Orthodoxy, by Richard A. Muller. Church History 66 (1997): 118-120.

BANGS, Carl. "Arminius as a Reformed Theologian.” In The Heritage of John Calvin. Heritage Hall Lectures, 1960-70, edited by John H. Bratt, 209-222. Grand Rapids, MI: Eerdmans, 1973.

BEACH, J. Mark. "Calvin and the Dual Aspect of Covenant Membership: Galatians 3:15-22— the Meaning of “'the seed' is Christ"- and Other Key Texts." Mid-America Journal of Theology 20 (2009): 49-73.

BoER, William den. “'Cum delectu': Jacob Arminius's (1559-1609) Praise for and Critique of Calvin and His Theology." Church History and Religious Culture 91 (2011): 73-86.

BuXAKowsKi, Jerzy. Laska Ducha Świętego i człowiek [The grace of the Holy Spirit and man]. Pelplin: Bernardinum, 2007.

CALvin, John. "Nauka religii chrześcijańskiej" [The Institutes of the Christian Religion], translated by Irmina Lichońska. In Myśl filozoficzno-religijna Reformacji XVI wieku [The philosophical and religious thought of the $16^{\text {th }}$-century Reformation], edited by Lech Szczucki, 277-416. Warsaw: PWN, 1972.

Calvin, John. "Tractatus Theologici Minores. Tomus Quintus.” In Ioannis Calvini Opera Quae Supersunt Omnia, edited by Edouard Cunitz, Johann-Wilhelm Baum, and Eduard Wilhelm Eugen Reuss. Vol. IX (Corpus Reformatorum. vol. XXXVII). Brunsvigae: C.A. Schwetschke et Filium, 1870.

CALvin, John. Institutio Christianae Religionis. Geneva: Oliua Roberti Stephani, 1559.

Calvin, John. The Institutes of the Christian Religion. Translated by Henry Beveridge. Grand Rapids, MI: Christian Classics Ethereal Library, 2002. The NTSLibrary (Online Christian Library of Virtual Theological Resources) http://www.ntslibrary.com/PDF\%20Books/Calvin\%20 Institutes $\% 20$ of\%20Christian\%20Religion.pdf (accessed: 20.01.2018).

COXHEAD, Steven R. "Deuteronomy 30:11-14 as a Prophecy of the New Covenant in Christ." Westminster Theological Journal 68 (2006): 305-320.

DOROCKI, Damian. "Doktryna predestynacji w teologii Jakuba Arminiusza" [The doctrine of predestination in Jacob Arminius' theology]. Teologia i Człowiek 35 (2016): 107-124.

DOROCKI, Damian. "Nieograniczone odkupienie i odparta łaska. Klasyczny arminianizm we współczesnej teologii ewangelikalnej" [Unlimited redemption and resistible grace. Classical Arminanism in contemporary evangelical theology]. Rocznik Teologiczny (ChAT) 58 (2016): 37-57.

HoRTon, Michael. Introducing Covenant Theology. Grand Rapids, MI: Baker Books, 2006.

Kanony Synodu w Dordrechcie [The Canons of Dort]. http://ekumenizm.wiara.pl/doc/478722. Kanony-Synodu-w-Dordrechcie-z-1618-roku (accessed: 23.11.2016).

LESZCZYŃSKI, Rafał Marcin. Ojcowie Reformacji i filozoficzne watki ich teologii [Fathers of the Reformation and the philosophical themes of their theology]. Warsaw: Wydawnictwo „Nowe Spojrzenia," 2010.

LIEBURG, Fred van. "Gisbertus Samuels, a Reformed Minister Sentenced by the Synod of Zeeland in 1591 for His Opinions on Predestination." In Revisiting the Synod of Dordt (1618-1619), edited by Aza Goudrian and Fred van Lieburg, 3-19. Leiden-Boston: Brill, 2011. 
Long, StePhen D. The Perfectly Simple Triune God. Aquinas and His Legacy. Minneapolis, MN: Fortress Press, 2016.

Macedo. Breno. "Covenant Theology in the Thought of John Calvin. From the Covenant of Works to the Abrahamic Covenant." Fides Reformata 20 (2015): 89-105.

MulLER Richard A. "The Covenant of Works and the Stability of Divine Law in SeventeenthCentury Reformed Orthodoxy: A Study in the Theology of Herman Witsius and Wilhelmus a Brakel." Calvin Theological Journal 29 (1994): 75-101.

Muller, Richard A. “Arminius and Scholastic Tradition.” Calvin Theological Journal 24 (1989): 263-277.

MulLeR, Richard A. "Historical and Theological Studies. Arminius and the Reformed Tradition." Westminster Theological Journal 70 (2008): 19-48.

MulLER, Richard A. Covenant and Conscience in English Reformed Theology. Three Variations on a $17^{\text {th }}$ Century Theme, Westminster Theological Journal 42 (1980): 308-334.

Muller, Richard A. Dictionary of Latin and Greek Theological Terms. Drawn Principally from Protestant Scholastic Theology. Grand Rapids, MI: Baker Academic, 1985.

Olson, Roger E. Historia teologii chrześcijańskiej. Dwadzieścia wieków tradycji i reform [The Story of Christian Theology: Twenty Centuries of Tradition Reform]. Translated by Konstanty Wiazowski. Warsaw: Chrześcijański Instytut Biblijny, 2003.

Olson, Roger E. Arminian Theology. Myths and Realities. Downers Grove, IL: InterVarsity Press, 2006.

PiCIRILli, Robert E. Grace, Faith, Free Will. Contrasting Views of Salvation: Calvinism \& Arminianism. Nashville, TN: Randall House Publications, 2002.

Robertson, O. Palmer. The Christ of the Covenants. Philipsburg: P\&R Publishing, 1980.

StANGLin, Keith D. Arminius on the Assurance of Salvation. The Context, Roots, and Shape of the Leiden Debate, 1603-1609. Leiden-Boston: Brill, 2007.

Stanglin, Keith D., and Thomas H. McCAll. Jacob Arminius. Theologian of Grace. New York, NY: Oxford University Press, 2012.

The Canons of Dort. Chapel Library (website), https://chapellibrary.org:8443/pdf/books/codo.pdf (accessed: 20.01.2018).

Thomas Aquinas, SAINT. Summa theologiae, http://www.corpusthomisticum.org/sth1015.html (accessed: 20.11.2016).

WitT, William Gene. "Creation, Redemption and Grace in the Theology of Jacob Arminius." PhD diss., University of Notre Dame, 1993.

Translated by Piotr Czyżewski

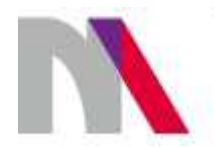

The preparation of the English version of Roczniki Teologiczne (Annals of Theology) and its publication in electronic databases was financed under contract no. 836/P-DUN/2018 from the resources of the Minister of Science and Higher Education for the popularization of science. 